\title{
Naphthalene Metabolism by Diatoms Isolated from the Kachemak Bay Region of Alaska
}

\author{
By CARL E. CERNIGLIA, ${ }^{1}$ DAVID T. GIBSON ${ }^{2}$ AND \\ CHASE VAN BAALEN ${ }^{3 *}$ \\ ${ }^{1}$ National Center for Toxicological Research, Food and Drug Administration, Jefferson, \\ Arkansas 72079, U.S.A. \\ ${ }^{2}$ Department of Microbiology, University of Texas at Austin, Austin, Texas 78712, U.S.A. \\ ${ }^{3}$ The University of Texas Marine Science Institute, Port Aransas Marine Laboratory, Port \\ Aransas, Texas 78373, U.S.A.
}

(Received 20 July 1981)

\begin{abstract}
Three pure cultures of diatoms - a Navicula sp., a Nitzschia sp. and a Synedra sp. - grown in the presence of naphthalene at 6 or $12^{\circ} \mathrm{C}$ oxidized the naphthalene to ethyl acetate-soluble and water-soluble metabolites. The major ethyl acetate-soluble metabolite was identified as 1-naphthol by gas chromatographic and mass spectral analysis. Experiments with $\left[{ }^{14} \mathrm{C}\right]$ naphthalene indicated that the extent of naphthalene metabolism ranged from 0.7 to $1.4 \%$.
\end{abstract}

\section{INTRODUCTION}

Aromatic hydrocarbons are widely distributed in open ocean waters (Brown \& Huffman, 1976). Many of these compounds and/or their metabolites have toxic properties, e.g. the initiation of tumour formation and cancer (Miller \& Miller, 1976). In studies of the fate of hydrocarbons in aquatic ecosystems, a considerable amount of information is available on the bacterial and fungal degradation of these compounds and their derivatives (Atlas, 1981; Cerniglia, 1981). In view of the fact that cyanobacteria and microalgae are widely distributed in many aquatic environments and may be important in the catabolism of hydrocarbons, we initiated a research programme on the algal oxidation of aromatic hydrocarbons (Cerniglia et $a l ., 1979,1980 a, b, c)$.

Most studies on the microbial oxidation of hydrocarbons have been conducted at temperatures between 20 and $30^{\circ} \mathrm{C}$, but the expansion of oil exploration and transport of petroleum in cold waters has given rise to increased interest in the microbial degradation of crude oil at low water temperatures (Atlas, 1981). In this investigation, we report on three diatoms isolated from the Kachemak Bay region of Alaska which can metabolize the aromatic hydrocarbon naphthalene at low temperatures.

\section{METHODS}

Organisms and growth conditions. The diatoms K1A (Navicula sp.), K8A (Nitzschia sp.) and 4D (Synedra sp.) were isolated by enrichment culture at 6 to $10^{\circ} \mathrm{C}$ from oblique net $(20 \mu \mathrm{m}$ Nitex nylon) tows made during August 1979 and April 1980, in the Kachemak Bay Region, south of Homer, Alaska. The enrichment medium was local sea water plus 5,20 or $50 \%$ (v/v) ASP-2 medium (Van Baalen, 1962). The ASP-2 basal medium contained, per litre, $18 \mathrm{~g} \mathrm{NaCl}, 5 \mathrm{~g} \mathrm{MgSO}_{4} .7 \mathrm{H}_{2} \mathrm{O}, 0.60 \mathrm{~g} \mathrm{KCl} 0.37 \mathrm{~g} \mathrm{CaCl}_{2} .2 \mathrm{H}_{2} \mathrm{O}, 1 \mathrm{~g} \mathrm{NaNO}, 0.05 \mathrm{~g} \mathrm{KH}_{2} \mathrm{PO}_{4}, 1 \mathrm{~g}$ Tris, $0.03 \mathrm{~g} \mathrm{Na}_{2}$ EDTA. $2 \mathrm{H}_{2} \mathrm{O}, 0.004 \mathrm{~g} \mathrm{FeCl}_{3} .6 \mathrm{H}_{2} \mathrm{O}, 0.034 \mathrm{~g} \mathrm{H}_{3} \mathrm{BO}_{3}, 0.004 \mathrm{~g} \mathrm{MnCl}_{2} .4 \mathrm{H}_{2} \mathrm{O}, 670 \mu \mathrm{g} \mathrm{ZnSO}_{4} .7 \mathrm{H}_{2} \mathrm{O}$, $38 \mu \mathrm{g} \mathrm{Na} \mathrm{MoO}_{4} \cdot 2 \mathrm{H}_{2} \mathrm{O}, 12 \mu \mathrm{g} \mathrm{CoCl}_{2} \cdot 6 \mathrm{H}_{2} \mathrm{O}$ and $0.3 \mu \mathrm{g} \mathrm{CuSO}_{4} \cdot 5 \mathrm{H}_{2} \mathrm{O}$, supplemented with $0.125 \mathrm{~g}$ $\mathrm{Na}_{2} \mathrm{SiO}_{3} \cdot 9 \mathrm{H}_{2} \mathrm{O}, 250 \mu \mathrm{g}$ thiamin and $4 \mu \mathrm{g}$ vitamin $\mathrm{B}_{12}$. Pure cultures were obtained by repeated streaking or by 
treatment with ultraviolet radiation $(254 \mathrm{~nm}, 15 \mathrm{~W}$ germicidal lamp) for several minutes and subsequent preparation of pour plates. Organism N-1 (Cylindrotheca sp.) was isolated from a water sample taken from the Pass adjacent to the Port Aransas Marine Laboratory (Estep et al., 1978). The organisms were grown in $20 \mathrm{ml}$ of supplemented ASP-2 medium (as above) in $22 \times 175 \mathrm{~mm}$ Pyrex test tubes at $12{ }^{\circ} \mathrm{C}$. The growth tubes were illuminated with two fluorescent lamps F20T12-WWX (Sylvania, Danvers, Mass., U.S.A.) on each side of the water bath, $8 \mathrm{~cm}$ from the front edge of the lamp to the the tube centre. The cultures were continuously aerated with air enriched with $1 \pm 0 \cdot 1 \%(\mathrm{v} / \mathrm{v}) \mathrm{CO}_{2}$. The generation times under these conditions for the four organisms were about $24 \mathrm{~h}$.

Naphthalene metabolism. Experiments using $\left[1^{-14} \mathrm{C}\right]$ naphthalene were done to determine the amount of naphthalene oxidized by each organism. Cells $(0.5-0.8 \mathrm{mg})$ were pooled from the growth tubes by allowing them to settle for several minutes and decanting the supernatant, and transferred to a $22 \times 175 \mathrm{~mm}$ screw-cap tube (final volume $10 \mathrm{ml}) .\left[{ }^{14} \mathrm{C}\right] \mathrm{Naphthalene}\left(1 \mu \mathrm{Ci}\right.$ in $20 \mu \mathrm{l}$ ethanol, $\left.6.9 \mathrm{mg}^{-1}\right)$ was added just before closing the tube with a plastic top lined with a chromatography septum, aluminium foil and 1 mil $\left(0.001\right.$ in) Teflon film. $\mathrm{CO}_{2}$ was added through a small hole in the plastic top with a gas-tight syringe to an initial concentration of $1 \%(\mathrm{v} / \mathrm{v})$. The screw-cap tubes were clamped to a glass rod and rotated slowly in the same illuminated water bath as used for growing the cultures. The tubes were incubated at either 6 or $12^{\circ} \mathrm{C}$. After $22 \mathrm{~h}$ incubation, cells were removed by centrifugation and each supernatant was extracted with five $30 \mathrm{ml}$ volumes of ethyl acetate. The organic extracts were dried over anhydrous $\mathrm{Na}_{2} \mathrm{SO}_{4}$ and the solvent was removed in vacuo at $42{ }^{\circ} \mathrm{C}$. Each residue was redissolved in methanol and analysed by high pressure liquid chromatography (h.p.l.c.). To determine the ratio of ethyl acetate-soluble metabolites to water-soluble metabolites, each organic-soluble extract was redissolved in $50 \mu \mathrm{l}$ acetone, and $10 \mu \mathrm{l}$ portions were added to vials containing $10 \mathrm{ml}$ scintillation fluid; $1 \mathrm{ml}$ of the aqueous phase was added to $10 \mathrm{ml}$ scintillation fluid. The radioactivity present was determined in a liquid scintillation counter. Corrections were made for machine efficiency and quenching.

An experiment with unlabelled naphthalene was conducted with organism K8A (Nitzschia sp.) in order to obtain sufficient material for the isolation and structure elucidation of the products of naphthalene metabolism. Four $10 \mathrm{ml}$ samples of organism K8A were incubated in screw-cap tubes as described above with $6.9 \mathrm{mg}$ naphthalene $1^{-1}$ at $12^{\circ} \mathrm{C}$. After $22 \mathrm{~h}$ the cells were centrifuged and the supernatant was extracted and concentrated as described above. The residue was redissolved in methanol and analysed by gas chromatography and mass spectrometry (GC-MS).

Analysis of metabolic products. All h.p.l.c. analyses were performed on a Beckman model 332 instrument with a model 155-10 variable wavelength absorbance detector (Beckman Instruments, Berkeley, Calif., U.S.A.) operated at $254 \mathrm{~nm}$. An Altex Ultrasphere-ODS column $(25 \mathrm{~cm} \times 4.6 \mathrm{~mm}$ i.d.; Altex Scientific, Berkeley, Calif., U.S.A.) was used for the separation of naphthalene metabolites, which was achieved with a programmed methanol/water

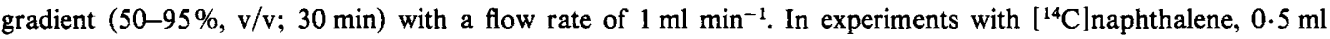
fractions were collected at $0.5 \mathrm{~min}$ intervals in scintillation vials and $5.0 \mathrm{ml}$ Aquasol-2 (New England Nuclear Corp., Boston, Mass., U.S.A.) was added to each vial. The radioactivity present in each fraction was determined in a Beckman LS-250 liquid scintillation counter.

GC-MS analysis of naphthalene metabolites was performed on a Finnigan model 3100 mass spectrometer coupled to a gas chromatograph equipped with a glass column $(2 \mathrm{~m} \times 1.5 \mathrm{~mm}$ i.d.) packed with $3 \% \mathrm{OV}-1$ on Chromosorb $\mathrm{Q}$. The injection temperature was $50^{\circ} \mathrm{C}$ with a temperature programme of $100-250{ }^{\circ} \mathrm{C}$ at $8{ }^{\circ} \mathrm{C}$ $\mathrm{min}^{-1}$. The carrier gas was helium, with a flow rate of $30 \mathrm{ml} \mathrm{min}{ }^{-1}$. The following conditions were used for mass spectrometry: molecular separator temperature, $350^{\circ} \mathrm{C}$; ion source temperature, $100^{\circ} \mathrm{C}$; ionization beam, $70 \mathrm{eV}$; ionization current, $200 \mu \mathrm{A}$.

Chemicals. Naphthalene (99.9\%) was from Aldrich Chemical Co., Milwaukee Wis., U.S.A. [1 $(4,5,8)-$ ${ }^{14} \mathrm{C}$ ]Naphthalene $\left[5 \mathrm{mCi} \mathrm{mmol}^{-1} ; 185 \mathrm{MBq} \mathrm{mmol}^{-1}\right.$ ) was from Amersham Searle, Arlington Heights, Ill. U.S.A. All naphthalene derivatives were purified as described previously (Cerniglia \& Gibson, 1977). Solvents for h.p.l.c. were purchased from Burdick and Jackson Laboratories, Muskegon, Mich., U.S.A.

\section{RESULTS AND DISCUSSION}

Three pure cultures of diatoms isolated from Alaskan waters (strains K8A, 4D and K1A) were incubated with $\left[{ }^{14} \mathrm{C}\right]$ naphthalene at either 6 or $12^{\circ} \mathrm{C}$. The h.p.l.c. elution profiles of the ethyl acetate-soluble naphthalene metabolites formed by each diatom are shown in Fig. $1(b, c$, d). For comparative purposes, the chromatographic properties of synthetic naphthalene derivatives are shown in Fig. 1(a). All of the organisms oxidized naphthalene to a compound which co-chromatographed with 1-naphthol. These results are similar to our earlier studies on the oxidation of naphthalene by cyanobacteria and microalgae (Cerniglia et al., 1980 b). 

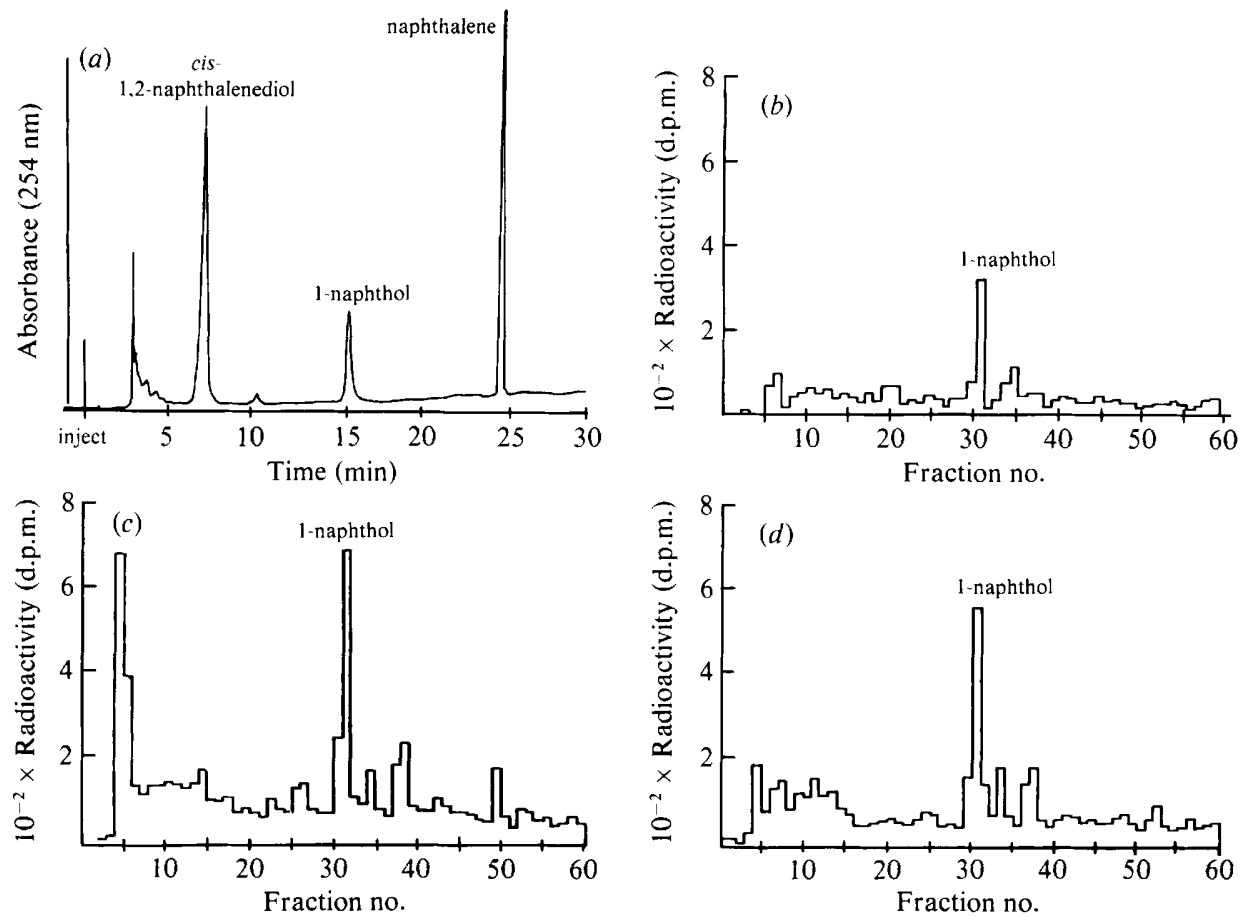

Fig. 1. H.p.l.c. elution profiles of ethyl acetate-soluble metabolites formed from $\left[1-{ }^{14} \mathrm{C}\right]$ naphthalene by different diatoms. (a) Resolution of a mixture of synthetic naphthalene derivatives. Metabolites formed by: (b) Nitzschia sp. strain K8A; (c) Synedra sp. strain 4D; (d) Navicula sp. strain K 1A. H.p.l.c. conditions were as described in Methods. Excess naphthalene was lost during the evaporation of ethyl acetate extracts of flask contents.

\section{Table 1. Distribution of radioactivity in the ethyl acetate-soluble and water-soluble metabolites formed from $\left[{ }^{14} \mathrm{C}\right]$ naphthalene by diatoms}

The $\left[1-{ }^{14} \mathrm{C}\right]$ naphthalene concentration was $6.9 \mathrm{mg}^{-1}(1 \mu \mathrm{Ci})$. Incubation was done in closed tubes. Naphthalene oxidation to $\mathrm{CO}_{2}$ was not determined. Medium and boiled organism controls were negative.

\begin{tabular}{lcccc}
\cline { 2 - 4 } Organism & $\begin{array}{c}\text { Distribution of radioactivity } \\
\text { Od.p.m. }(\mathrm{mg} \mathrm{cell} \mathrm{dry} \mathrm{wt)}\end{array}$ & Total & $\begin{array}{c}\text { Percentage } \\
\text { metabolism } \\
\text { of naphthalene }\end{array}$ \\
sp. strain K8A & $8965(49)^{*}$ & $9311(51)$ & 18276 & 0.8 \\
sp. strain 4D & $18044(58)$ & $13332(42)$ & 31376 & 1.4 \\
sp. strain K1A & $9658(55)$ & $7987(45)$ & 17645 & 0.8 \\
heca sp. strain N-1 & $6550(43)$ & $8784(57)$ & 15334 & 0.7
\end{tabular}

* Numbers in parentheses indicate the percentage of total metabolites.

In order to confirm that 1-naphthol was the major metabolite in the oxidation of naphthalene, cells of Nitzschia sp. strain K8A were incubated for $22 \mathrm{~h}$ in the presence of naphthalene and the ethyl acetate-soluble extract was analysed by GC-MS. The GC-MS analysis of this extract showed a compound that had a similar retention time $(9.5 \mathrm{~min})$ and mass spectrum ( $m / e$ 144) to that of authentic 1-naphthol.

Table 1 shows that these diatoms oxidized naphthalene to both organic-soluble and water-soluble derivatives. The amount of naphthalene oxidized to recoverable products ranged 
from 0.7 to $1.4 \%$. It is interesting to note that Cylindrotheca sp. strain $\mathrm{N}-1$ grown at $12{ }^{\circ} \mathrm{C}$, conditions in which it had a similar growth rate to organism $4 \mathrm{D}$, oxidized less naphthalene (Table 1). These data suggest that cold-adapted microalgae may prove to be more metabolically active than might be thought from their slow growth rates.

In an earlier study we showed that the cyanobacterium Oscillatoria sp. strain JCM oxidized $4.8 \%$ of the added naphthalene (Cerniglia et al., 1980a). The ratio of ethyl acetate-soluble metabolites to water-soluble metabolites was 41:59. Table 1 shows that all of the diatoms formed water-soluble products. The identity of these products remains to be determined but the results suggest that diatoms may be able to convert naphthalene to ring cleavage products or to form conjugated compounds.

These results extend the original observations on the oxidation of naphthalene by temperate forms (Cerniglia et al., 1980b) to cold-adapted diatoms and reinforce the view that the capacity for oxidation of aromatic compounds is a general metabolic feature in the microalgae. Algal rates of aromatic oxidation compared with rates for the aerobic heterotrophic microbial populations in the photic zone are unknown. However, the photic zone in the sea may prove to be a major sink for transformations of aromatic compounds in nature. Whether this will increase or decrease their toxicity for zooplankton and higher trophic levels is unknown.

We are grateful to Drs Rita Horner and Robert A. Gibson for the identification of the cultures. This study was funded in part by the Bureau of Land Management through interagency agreement with the National Oceanic and Atmospheric Administration, as part of the Outer Continental Shelf Environmental Assessment Program.

\section{REFERENCES}

Atlas, R. M. (1981) Microbial degradation of petroleum hydrocarbons: an environmental perspective. Microbiological Reviews 45, 180-209.

Brown, R. A. \& Huffman, H. L., JR (1976). Hydrocarbons in open ocean waters. Science 191, 847-849.

Cerniglia, C. E. (1981). Aromatic hydrocarbons: metabolism by bacteria, fungi and algae. In Reviews in Biochemical Toxicology, vol. 3, pp. 321-361. Edited by E. Hodgson, J. R. Bend \& R. M. Philpot. New York: Elsevier/North Holland.

Cerniglia, C. E. \& Gibson, D. T. (1977). Metabolism of naphthalene by Cunninghamella elegans. Applied and Environmental Microbiology 34, 363-370.

Cerniglia, C. E., Gibson, D. T. \& Van BaAlen, C. (1979). Algal oxidation of aromatic hydrocarbons: formation of 1-naphthol from naphthalene by Agmenellum quadruplicatum, strain PR-6. Biochemical and Biophysical Research Communications 88, 50-58.

Cerniglia, C. E., Van BaAlen, C. \& Gibson, D. T. $(1980 a)$. Metabolism of naphthalene by the cyanobacterium Oscillatoria sp., strain JCM. Journal of General Microbiology 116, 485-494.
Cerniglia, C. E., Gibson, D. T. \& Van BaAlen, C. $(1980 \mathrm{~b})$. Oxidation of naphthalene by cyanobacteria and microalgae. Journal of General Microbiology 116, 495-500.

Cerniglia, C. E., Van BaAlen, C. \& Gibson, D. T. $(1980 c)$. Oxidation of biphenyl by the cyanobacterium Oscillatoria sp. strain JCM. Archives of Microbiology 125, 203-209.

Estep, M. F., Tabita, F. R. \& Van BaAlen, C. (1978). Purification of ribulose 1,5-bisphosphate carboxylase and carbon isotope fractionation by whole cells and carboxylase from Cylindrotheca sp. (Bacillariophyceae). Journal of Phycology 14, 183188.

Miller, E. C. \& Miller, J. A. (1976). The metabolism of chemical carcinogens to reactive electrophiles and their possible mechanisms of action in carcinogenesis. In Chemical Carcinogens, pp. 737762. Edited by C. E. Searle. Washington, D.C.: American Chemical Society.

VAN BAALEN, C. (1962). Studies on marine blue-green algae. Botanica marina 4, 129-139. 